\title{
PENGARUH PELATIHAN, KOMPETENSI DAN KOMITMEN TERHADAP KINERJA PETUGAS AIR TRAFFIC CONTROLLER ( ATC ) PADA PERUSAHAAN UMUM (PERUM) PENYELENGGARA PELAYANAN NAVIGASI PENERBANGAN INDONESIA ( LPPNPI ) CABANG MEDAN
}

\author{
${ }^{1}$ Lucky Andri Rianto, ${ }^{2}$ Ibnu Zaiyyat Indra, ${ }^{3}$ Butar Marulitua Manurung, ${ }^{4}$ Rosdiana, ${ }^{5}$ Juan Madya Edri \\ $1,2,3,4,5$ Universitas Islam Sumatera Utara \\ ${ }^{1}$ lucky.andrianto@gmail.com, ${ }^{2}$ ibnu.zaiyatindra@gmail.com, ${ }^{3}$ butar.marulitua@gmail.com, \\ ${ }^{4}$ rosdiana.mm@gmail.com, ${ }^{5}$ juan.madyaedri@gmail.com
}

\begin{abstract}
Air Traffic Controllers (ATC) or Air Traffic Guides are one of the keys to aviation services because they are people who serve flights from the tip of Sumatra island to the tip of Papua. Thousands of aircraft are serviced every day with arranged arrangements to avoid collisions, delays and flight schedule chaos. The great responsibility assigned to ATC makes them have specificities in education, training, competence and health standards that are different from other human resources. This study aims to determine, review and analyze training, competence, and commitment to the performance of ATC officers at PERUM LPPNPI Medan Branch. The design of this study was a descriptive analytic and quantitative survey of 71 ATC officers who worked at PERUM LPPNPI Medan as the research sample. The research data were collected by making a list of questions (questionare), interviews and documentation study. The research data will be tested using classic assumption tests (normality test, multicollinearity, heteroscedasticity) and hypothesis testing ( $t$ and $f$ tests, determinant test).The results showed that (1) the training had a pvalue (in the Sig. Column) 0.03>0.05, which means that it was significant, while the t count of 2.705 was greater than the t table of 1.995. (2) Competence has a p-value (in the Sig. Column) $0.00>0.05$, which means significant, or $t$ count 6,358 is greater than $t$ table 1.995. (3) The commitment variable has a p-value (in the Sig. Column) of $0.01<0.05$, which means significant, while the $t$ count is 3.654> from the t table 1.995. This means that training, competence and commitment have a positive and significant effect on employee performance. Based on the research results, the following suggestions can be made: (1) Perum LPPNPI Medan Branch to further improve training evenly and continuously for the purpose of providing optimal air traffic guidance services to be realized, (2) it is necessary to promote regular discussion forums in discussing problems that occur and share the latest knowledge, (3) need to reward employees according to work performance, for example: training or educational rewards outside of their knowledge for future development, giving praise, giving certificates or souvenirs for employees, (4) leaders need fostering a trustworthy attitude towards employees can increase employee creativity and initiative, and (5) companies need to provide rewards and better monitor the performance improvement of each employee by making and publishing reports on a regular basis regarding their performance.
\end{abstract}

Keywords: Training, Competence, Commitment, Employee Performance

\begin{abstract}
ABSTRAK : Air Traffic Controller ( ATC) atau Pemandu Lalu Lintas Udara merupakan salah satu kunci pelayanan penerbangan karena mereka adalah orang orang yang melayani penerbangan dari ujung pulau Sumatera sampai dengan ujung Papua. Ribuan pesawat dilayani setiap harinya dengan pengaturan yang sudah tertata agar terhindar dari tabrakan, keterlambatan dan kekacauan jadwal penerbangan. Tanggung jawab besar yang dibebankan kepada ATC menjadikan mereka harus memiliki kekhususan dalam pendidikan, pelatihan, kompetensi dan standar kesehatan yang berbeda dengan sumber daya manusia lainnya. Penelitian ini bertujuan untuk mengetahui, mengkaji dan menganalisis pengaruh pelatihan, kompetensi, dan komitmen terhadap kinerja petugas ATC di PERUM LPPNPI Cabang Medan. Desain penelitian ini adalah survei yang bersifat deskriptif analitik dan kuantitatif analitik terhadap 71 petugas ATC yang
\end{abstract}


bekerja di PERUM LPPNPI Cabang Medan sebagai sampel penelitian. Data penelitian dikumpulkan dengan membuat daftar pertanyaan (questionare), wawancara dan studi dokumentasi. Data penelitian akan diuji dengan menggunakan uji asumsi klasik (uji normalitas, multikolinearitas, heterokedastisitas) dan uji hipotesa ( uji $t$ dan $f$, uji determinan). Hasil penelitian menunjukkan bahwa (1) pelatihan memiliki nilai p-value (pada kolom Sig.) 0,03>0,05 artinya signifikan, sedangkan $t$ hitung 2.705 lebih besar dari dari $t$ table 1.995. (2) Kompetensi memiliki nilai p-value (pada. kolom Sig.) 0,00> 0,05 artinya signifikan, atau $t_{\text {hitung }} 6.358$ lebih besar dari $t_{\text {tabel }}$ 1.995. (3) Variabel komitmen memiliki nilai p-value (pada kolom Sig.) 0,01<0,05 artinya signifikan, sedangkan $t_{\text {hitung }}$ 3.654> dari $t$ table 1.995. Hal ini berarti bahwa pelatihan, kompetensi dan komitmen berpengaruh positif dan signifikan terhadap kinerja pegawai. Berdasarkan hasil penelitian dapat dikemukakan saran-saran sebagai berikut: (1) Perum LPPNPI Cabang Medan agar lebih meningkatkan pelatihan secara merata dan berkelanjutan untuk tujuan pemberian pelayanan pemanduan lalu lintas udara yang optimal dapat terwujud, (2) perlu menggalakkan forum diskusi secara rutin dalam membahas permasalahan yang terjadi dan saling berbagi pengetahuan terbaru, (3) perlu memberikan penghargaan kepada pegawai sesuai dengan prestasi kerja, misalnya: reward pelatihan atau pendidikan diluar keilmuannya untuk pengembangan masa depannya, pemberian pujian, pemberian setifikat atau cendramata bagi pegawai, (4) pimpinan perlu menumbuhkan sikap dapat dipercaya kepada pegawai dapat meningkatkan kreativitas dan inisiatif pegawai, dan (5) perusahaan perlu memberikan reward dan lebih memantau peningkatan kinerja setiap karyawan dengan membuat dan mempublish laporan secara rutin terkait kinerjanya..

Kata kunci : Pelatihan, Kompetensi, Komitmen, Kinerja Pegawai

\section{Pendahuluan}

Peningkatan jumlah penerbangan menjadi masalah pada tingkat keamanan dan keselamatan penerbangan, perlu dilakukan pengaturan lalu lintas udara agar tercapai tingkat keselamatan, keamanan dan efisiensi yang tinggi sesuai dengan standar yang telah ditetapkan oleh International Civil Aviation Organization ( ICAO ). Perusahaan umum Lembaga Penyelenggara Pelayanan Navigasi Penerbangan Indonesia (Perum LPPNPI) atau AirNav Indonesia merupakan salah satu operator pemberi jasa penerbangan yang memiliki tugas pokok dan tanggung jawab besar terhadap pemberian pelayanan lalu lintas udara, target zero accident merupakan batasan minimal yang harus dicapai sehingga mau tidak mau sumber daya manusia, dimana salah satunya adalah petugas Air Traffic Controller (ATC) yang bertanggung jawab dalam pengaturan lalu lintas udara harus handal, memiliki kemampuan, pengetahuan/ wawasan, kecakapan dan sikap yang bisa menjadi pedoman dalam melakukan tanggung jawabnya.

Air Traffic Controller (ATC) atau Pemandu Lalu Lintas Udara merupakan salah satu kunci pelayanan penerbangan karena mereka adalah orang orang yang melayani penerbangan dari ujung pulau Sumatera sampai dengan ujung Papua. Ribuan pesawat dilayani setiap harinya dengan pengaturan yang sudah tertata agar terhindar dari tabrakan, keterlambatan dan kekacauan jadwal penerbangan. Tanggung jawab besar yang dibebankan kepada ATC menjadikan mereka harus memiliki kekhususan dalam pendidikan, pelatihan, kompetensi dan standar kesehatan yang berbeda dengan sumber daya manusia lainnya. Pelatihan dan pengembangan harus rutin dilakukan, karena pertumbuhan ilmu dan teknologi yang sangat pesat mengharuskan ATC dapat menyesuaikan diri agar tidak tertinggal dengan kemajuan teknologi tersebut.

Suatu organisasi akan dapat mencapai tujuan organisasinya bila didukung oleh sumber daya manusia yang berkualitas. Salah satu faktor pendukung yang sangat penting untuk mempersiapkan sumber daya manusia yang berkualitas adalah melalui kegiatan pelatihan. Seperti diketahui secara umum, pelatihan merupakan suatu usaha untuk mengembangkan sumber daya manusia terutama dalam hal pengetahuan, kemampuan, keahlian dan sikap. Pelatihan harus sering dilakukan dan kesempatan mengikutinya juga harus dirasakan oleh seluruh sumber daya manusia. Pengembangan juga perlu ditingkatkan agar para karyawan tidak hanya mendapatkan ilmu teknis pekerjaan saja tapi perlu peningkatan dalam ilmu ilmu lain yang dapat mendukung karirnya di kemudian hari. Hal ini bertujuan agar kinerja yang diberikan oleh karyawan 
dapat maksimal dan dapat memberikan keuntungan bagi organisasi.

Suatu organisasi walaupun didukung oleh fasilitas dan sumber dana yang banyak, tetapi tanpa dukungan sumber daya manusia yang handal yang memiliki kemampuan, kecakapan, pengetahuan dan prilaku yang baik maka misi organisasi tidak akan tercapai. Hal ini menunjukkan bahwa kompetensi merupakan kunci pokok yang harus diperhatikan secara serius dalam menentukan keberhasilan pelaksanaan kegiatan organisasi. Tuntutan organisasi untuk memperoleh, mengembangkan dan mempertahankan sumber daya manusia yang berkualitas semakin mendesak sesuai perkembangan zaman. Kompetensi sumber daya manusia harus sejak dini dipersiapkan dan selalu ditingkatkan secara maksimal, hal ini merupakan strategi untuk meningkatkan efisiensi, efektif dan sikap tanggap dalam rangka peningkatan kinerja organisasi dalam mencapai tujuan yang di targetkan.

Sumber daya manusia di suatu organisasi, harus mempunyai komitmen dalam bekerja karena jika tidak mempunyai komitmen dalam bekerja, maka tujuan dari perusahaan atau organisasi tersebut tidak akan tercapai. Namun terkadang suatu perusahaan atau organisasi kurang memperhatikan komitmen yang ada terhadap karyawannya, sehingga berdampak pada penurunan kinerja terhadap karyawan ataupun loyalitas karyawan menjadi berkurang. Komitmen pada setiap karyawan sangat penting karena dengan suatu komitmen seorang karyawan dapat menjadi lebih bertanggung jawab terhadap pekerjaannya dibanding dengan karyawan yang tidak mempunyai komitmen. Biasanya karyawan yang memiliki suatu komitmen, akan bekerja secara optimal sehingga dapat mencurahkan perhatian, pikiran, tenaga dan waktunya untuk pekerjaanya, sehingga apa yang sudah dikerjakannya sesuai dengan yang diharapkan oleh perusahaan.

Banyak fenomena yang terjadi dalam sebuah perusahaan terkait pelatihan kompetensi dan komitmen dalam mempengaruhi kinerja para karyawan. Banyak perusahaan yang rugi, bangkrut bahkan tutup, hal ini karena minimnya pelatihan sehingga kemampuan dan pengetahuan karyawan terbatas dalam beradaptasi dengan kemajuan teknologi, kompetensi yang tidak maksimal sehingga menyebabkan tidak produktifnya karyawan, komitmen yang kurang baik sehingga mengakibatkan kurangnya tanggung jawab dan rasa memiliki perusahaan. Hal ini berpengaruh terhadap penurun kinerja karyawan.

Fenomena fenomena terkait pelatihan, kompetensi dan komitmen juga terjadi di AirNav cabang Medan. Pelatihan yang didapatkan para petugas ATC pada saat ini belum merata sehingga terjadi perbedaan keterampilan dan persepsi dalam menyelesaikan masalah, kemudian tidak meratanya kompetensi dan berakibat timbul ketidak percayaan akan kemampuan petugas dalam menyelesaikan pekerjaan lalu kurangnya komitmen karyawan sehingga timbul ketidak pedulian terhadap aturan dan kondisi perusahaan.

Tabel 1. Daftar absensi petugas ATC

\begin{tabular}{|c|c|c|c|c|c|c|}
\hline TAHUN & $\begin{array}{c}\text { JUMLAH } \\
\text { PETUGAS }\end{array}$ & $\begin{array}{c}\text { MANGKIR/ } \\
\text { ABSEN }\end{array}$ & $\%$ & $\begin{array}{c}\text { LAMBAT } \\
\text { DATANG } \\
\text { PULANG } \\
\text { CEPAT }\end{array}$ & $\%$ & $\begin{array}{c}\text { TOTAL } \\
\text { PERSENTASE }\end{array}$ \\
\hline $\begin{array}{c}\text { TAHUN } \\
\mathbf{2 0 1 8 / J U N I}\end{array}$ & 80 & 270 & 0,48 & 786 & 1,4 & 2,88 \\
\hline $\begin{array}{c}\text { TAHUN } \\
\mathbf{2 0 1 9}\end{array}$ & 85 & 20 & 0,02 & 458 & 0.45 & 0.47 \\
\hline
\end{tabular}

Sumber : Data AirNav Indonesia cabang Medan, 2019

Berdasarkan Tabel 1, di atas, tingkat disiplin kehadiran karyawan kurang baik, dimana masih banyak karyawan yang mangkir atau absen tanpa pemberitahuan dan banyak karyawan yang datang telat dan pulang cepat. Hal ini disebabkan karena rendahnya komitmen karyawan sehingga timbulah pelanggaran pelanggaran aturan. Menurut penelitian, hal hal tersebut diatas dapat diakibatkan karena kurangnya pelatihan untuk meningkatkan kompetensi dalam pengembangan karyawan, minimnya komitmen karyawan dan juga kurangnya perusahaaan memberikan sanksi kepada karyawan yang melangar peraturan disebabkan kurangnya pengawasan dari pimpinan.

Kinerja pegawai menjadi tolak ukur bagi keberhasilan pegawai dalam melaksanakan 
tugas dan pekerjaan yang menjadi tanggung jawabnya, dan apabila terjadi penurunan kinerja, maka harus diupayakan untuk mencari faktor penyebabnya, kemudian dicarikan pemecahan masalahnya agar tidak menjadi berlarut-larut yang nantinya dapat menghambat pencapaian tujuan.

Tanda tanda penurunan kinerja pegawai dilihat dari sikap terhadap pekerjaannya, seperti produktifitas berkurang, kualitas kerja menurun, tidak bisa menepati jadwal, menghindar dari penugasan yang lebih menantang, tidak dapat memfokuskan diri pada tugas-tugas yang penting, kurangnya tanggung jawab atas pekerjaan, hasil kerja yang diperoleh tidak maksimal atau tidak sesuai standar atau target yang diharapkan dan pada akhirnya dapat mengakibatkan rendahnya mutu pelayanan.

\subsection{Batasan Masalah}

Mengingat banyaknya faktor yang dapat menyebabkan peningkatan atau penurunan kinerja seorang pegawai yang tidak mungkin dapat diamati secara keseluruhan, maka kajian penelitian ini hanya dibatasi pada pengaruh pelatihan, kompetensi dan komitmen terhadap kinerja petugas Air Traffic Controller ( ATC) pada AirNav cabang Medan

\subsection{Hioptesis}

Berdasarkan data-data yang telah diperoleh penulis dapat dirumuskan hipotesis sebagai berikut :

1) Terdapat Pengaruh Positif dan Signifikan antara Pelatihan terhadap Kinerja Petugas Air Traffic Controller pada Perum Lembaga Penyelenggara Pelayanan Navigasi Penerbangan Indonesia ( LPPNPI ) Cabang Medan

2) Terdapat pengaruh Positif dan Signifikan antara Kompetensi terhadap Kinerja Petugas Air Traffic Controller Pada Perum Lembaga Penyelenggara Pelayanan Navigasi Penerbangan Indonesia ( LPPNPI ) Cabang Medan

3) Terdapat pengaruh Positif dan Signifikan antara Komitmen terhadap Kinerja Petugas Air Traffic Controller pada Perum Lembaga Penyelenggara Pelayanan Navigasi Penerbangan Indonesia ( LPPNPI ) Cabang Medan.

4) Terdapat pengaruh Positif dan Signifikan antara Pelatihan, Kompetensi dan Komitmen terhadap terhadap Kinerja Petugas Air Traffic Controller pada Perum Lembaga
Penyelenggara Pelayanan Navigasi Penerbangan Indonesia ( LPPNPI ) Cabang Medan.

\subsection{Tujuan Penelitian}

Tujuan penelitian ini adalah untuk mengetahui, menganalisis dan mengkaji :

1) Pengaruh Pelatihan terhadap Kinerja Petugas Air Traffic Controller ( ATC) pada AirNav cabang Medan

2) Pengaruh kompetensi terhadap Kinerja Air Traffic Controller ( ATC ) pada AirNav cabang Medan

3) Pengaruh Komitmen terhadap Kinerja Petugas Air Traffic Controller ( ATC) pada AirNav cabang Medan

4) Pengaruh Pelatihan, kompetensi dan komitmen serta Kinerja Petugas Air Traffic Controller (ATC) pada AirNav cabang Medan.

\section{Metode Penelitian}

\subsection{Populasi dan Sampel}

Kata populasi (population/ universe) dalam statistika merujuk pada sekumpulan individu dengan karakteristik khas yang menjadi perhatian dalam suatu penelitian (pengamatan).

Menurut Sugiyono (2019:285) “ Populasi adalah wilayah generalisasi yang terdiri atas obyek atau subyek yang mempunyai kualitas dan karakteristik tertentu yang ditetapkan oleh peneliti untuk dipelajari dan kemudian ditarik kesimpulannya". Populasi dalam penelitian ini adalah seluruh Petugas Air Traffic Control Perum LPPNPI cabang Medan yang berjumlah 71 orang.

Pengukuran sampel merupakan suatu langkah untuk menentukan besarnya sampel yang diambil dalam melaksanakan penelitian suatu objek. Untuk menentukan besarnya sampel bisa dilakukan dengan statistik atau berdasarkan estimasi penelitian. Pengambilan sampel ini harus dilakukan sedemikian rupa sehingga diperoleh sampel yang benar benar dapat berfungsi atau dapat menggambarkan keadaan populasi yang sebenarnya, dengan istilah lain harus representatif (mewakili)", teknik penarikan sampel pada penelitian ini adalah dengan menggunakan teknik total sampling dimana seluruh populasi dijadikan sampel sabanyak 71 orang. 


\subsection{Uji Normalitas}

\section{Normal P-Plot Of Regression Standardized Residual}

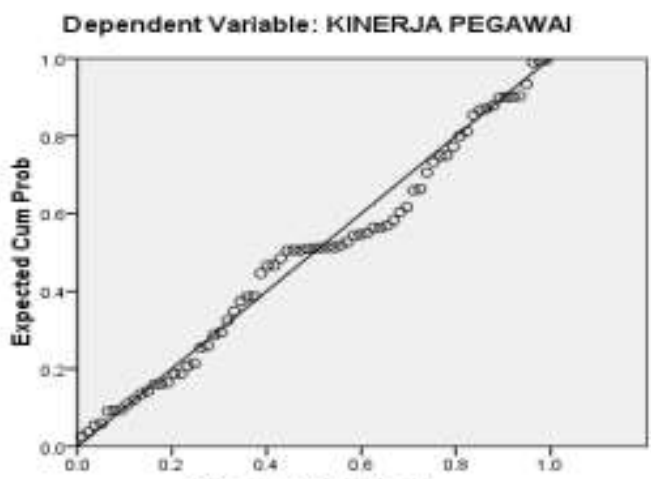

Observed Cum Prob

Gambar 1.Grafik Uji Normalitas Data

Berdasarkan gambar 1 di atas, data penelitian tentang pengaruh pelatihan, kompetensi dan komitmen terhadap kinerja pegawai yang dilakukan di Perum LPPNPI Cabang Medan dengan menggunakan software SPSS statistic diketahui bahwa titik ploting menyebar disekitar garis diagonal dan mengikuti arah garis diagonal pada grafik uji pplot tersebut diatas. Hal ini menunjukkan bahwa model regresi atau pengaruh antar variabel penelitian adalah terdistribusi normal. Jadi dapat disimpulkan bahwa berdasarkan grafik P-P plot, model regresi memenuhi asumsi normalitas.

\subsection{Uji Multikohnieritas}

Tabel 2. Uji Multikohnieritas Coefficientsa

\begin{tabular}{|l|l|r|r|}
\hline \multicolumn{2}{|l|}{ Model } & \multicolumn{2}{c|}{ Collinearity Statistics } \\
\cline { 3 - 4 } \multicolumn{2}{|l}{} & \multicolumn{1}{c|}{ Tollerance } & VIF \\
\hline \multirow{3}{*}{1} & Pelatihan & .583 & 1.716 \\
\cline { 2 - 4 } & Kompetensi & .618 & 1.618 \\
\cline { 2 - 4 } & Komitmen & .678 & 1.476 \\
\hline
\end{tabular}

Dependent Variable: Kinerja_Pegawai

Melihat hasil besaran nilai tolerance menunjukkan tidak ada variabel independen yang rnemiliki nilai tolerance kurang dari 0,10 , yang berarti tidak ada korelasi antar variabel independen atau tidak terjadi multikolinieritas. Hasil perhitungan nilai variance inflation factor (VIF) juga menunjukkan hal yang sama tidak ada satu variabel independen yang memiliki nilai VIF lebih dari 10,00.

Sesuai hasil pengolahan data penelitian tentang pengaruh pelatihan, kompetensi dan komitmen terhadap kinerja pegawai yang dilakukan di Perum LPPNPI Cabang Medan diketahui bahwa nilai VIF masing- masing variabel independen dalam penelitian adalah lebih kecil dari 10.00. Berdasarkan hasil penelitian diketahui bahwa nilai tolerance dari 3 variabel yakni pelatihan, kompetensi, dan komitmen lebih kecil dari 10, atau pelatihan $\mathrm{VIF}=1.716$, kompetensi $\mathrm{VIF}=1.618$, komitmen VIF $=1.476<10.00$ maka dapat disimpulkan bahwa terdapat hubungan yang sangat kuat antar variabel independen dalam penelitian ini.

Jadi dapat disimpulkan bahwa tidak ada multikolinieritas antar variabel independen dalam model regresi.

\subsection{Uji Heteroskedastisitas}

Dengan pengolahan data penelitian yang dilakukan di Perum LPPNPI Cabang Medan diketahui melalui ploting dalam gambar 5.2. Pengujian asumsi heteroskedastisitas menyimpulkan bahwa model regresi tidak terjadi heteroskedastisitas. Dengan kata lain terjadi kesamaan varian dari residual dari satu pengamatan ke pengamatan yang lain. Dalam plot dibawah ini terjadi penyebaran titik tidak memperlihatkan adanya pola tertentu maka dapat disimpulkan tidak terjadinya heteroskedastisitas. Hasil uji heteroskedastisitas dapat dilihat pada gambar 2 berikut ini:

\section{Scatterplot}

Dependent Variable:KinerjaPegawai

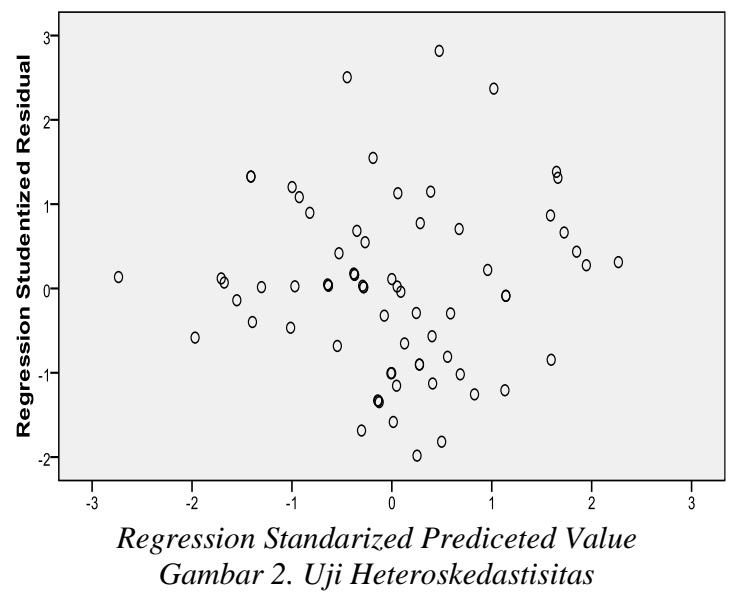

\section{Pengujian Hipotesis}

\subsection{Hasil Persamaan Regresi}

Untuk mempermudah pembacaan hasil dan interpretasi analisis regresi maka digunakan bentuk persamaan. Persamaan atau model tersebut berisi konstanta dan koefisien-koefisien regresi yang didapat dari hasil pengolahan data yang telah dilakukan sebelumnya. 
Tabel 3. Uji Regresi Linier Berganda Coefficients $^{\mathrm{a}}$

\begin{tabular}{|c|l|r|r|r|r|r|}
\hline \multirow{2}{*}{ Model } & \multicolumn{2}{|c|}{ Unstandardized Coefficient } & Unstandardized & & \\
\cline { 3 - 4 } & B & Std. Error & Coefficient & t & \multicolumn{1}{c|}{ Sig } \\
\hline 1 & (Constant) & 0.144 & 2.474 & & 0.058 & .954 \\
\hline & Pelatihan & 0.286 & 0.106 & .224 & 2.705 & .003 \\
\hline & Kompetensi & 0.459 & 0.072 & .512 & 6.358 & .000 \\
\hline \multicolumn{2}{|l|}{ Komitmen } & 0.241 & 0.066 & .281 & 3.654 & .001 \\
\hline
\end{tabular}

Setelah pengolahan data penelitian diketahui bahwa persamaan regresi dirumuskan dan persamaan akhir yaitu :

$\mathrm{Y}=0.144+0,286 \mathrm{X}_{1}-0,459 \mathrm{X}_{2}+0.241 \mathrm{X}_{3}$

Pada model regresi ini, P-nilai konstanta yang tercantum sebesar 0.144 dapat diartikan jika variabel bebas dalam model diasumsikan sama dengan nol atau variabel bebas dalam hal ini yaitu pelatihan (X1), kompetensi (X2) dan komitmen (X3) dapat diterapkan, maka kinerja pegawai akan mengalami kenaikan sebesar 0.144 satuan.

Nilai besaran koefisien regresi $\beta_{1}$ sebesar 0,286 pada penelitian ini dapat diartikan bahwa variabel pelatihan (X1) berpengaruh terhadap kinerja pegawai (Y). Hal ini menunjukkan bahwa ketika kompetensi terpenuhi, maka kinerja pegawai akan naik 0,286 satuan.

Nilai besaran koefisien regresi $\beta 2$ sebesar 0,459 pada penelitian ini dapat diartikan bahwa variabel kompetensi (X2) berpengaruh terhadap kinerja pegawai (Y). Hal ini menunjukkan bahwa ketika variabel kompetensi terpenuhi, maka kinerja pegawai akan naik 0,384 satuan.

Nilai besaran koefisien regresi $\beta 3$ sebesar 0.241 pada penelitian ini dapat diartikan bahwa variabel komitmen (X3) berpengaruh positif terhadap kinerja pegawai (Y). Hal ini menunjukkan bahwa ketika variabel komitmen terpenuhi, maka kinerja pegawai akan naik/baik

\subsection{Pengujian Hipotesis dengan Uji - $t$}

Pengujian hipotesis dengan uji $t$, yaitu dengan memperhatikan nilai $t$ hitung dari hasil regresi tersebut untuk mengetahui pengaruh variabel independen secara parsial terhadap variabel dependen dengan tingkat signifikansi dalam penelitian ini menggunakan alpha 5\% atau 0,05 . Nilai dari uji $t_{\text {hitung }}$ dapat dilihat dari p-value (pada kolom Sig.) pada masing-masing variabel independen, jika p-value lebih kecil dari level of significant yang ditentukan atau $\mathrm{t}$ hitung (pada kolom $t$ ) lebih besar dari $t_{\text {tabel }}$ (dihitung dari two-tailed $\alpha=5 \%$ df- $\mathrm{k}, \mathrm{k}$ merupakan jumlah variabel independen), maka nilai variabel independen secara parsial berpengaruh signifikan terhadap variabel dependen (dalam arti $\mathrm{Ha}$ diterima dan $\mathrm{Ho}$ ditolak, dengan kata lain, terdapat pengaruh antara variabel independen terhadap variabel dependen).

Adapun metode dalam penentuan $t$ tabel sesuai data penelitian tentang yang dilakukan di Perum LPPNPI Cabang Medan dimana terdapat 3 variabel bebas yakni pelatihan, kompetensi, dan komitmen adalah menggunakan ketentuan tingkat signifikan 5\%, dengan :

$\mathrm{df}=(\mathrm{n} .-\mathrm{k})-1, \quad \mathrm{df}=(71-3)-1=67$, sehingga didapat nilai $\mathrm{t}_{\text {tabel }}$ sebesar 1.995.

Tabel 4 Uji parsial (Uji t)

Coefficients $^{\mathrm{a}}$

\begin{tabular}{|c|c|c|c|c|c|c|}
\hline \multirow{2}{*}{\multicolumn{2}{|c|}{ Model }} & \multicolumn{2}{|c|}{$\begin{array}{l}\text { Unstandardized } \\
\text { Coefficient }\end{array}$} & \multirow{2}{*}{$\begin{array}{c}\text { Unstandardized } \\
\text { Coefficient }\end{array}$} & \multirow[b]{2}{*}{$\mathrm{t}$} & \multirow[b]{2}{*}{ Sig } \\
\hline & & B & Std. Error & & & \\
\hline \multirow[t]{4}{*}{1} & (Constant) & 0.144 & 2.474 & & 0.058 & .954 \\
\hline & Pelatihan & 0.286 & 0.106 & .224 & 2.705 & .003 \\
\hline & Kompetensi & 0.459 & 0.072 & .512 & 6.358 & .000 \\
\hline & Komitmen & 0.241 & 0.066 & .281 & 3.654 & .001 \\
\hline
\end{tabular}

Dependent Variable: Kinerja_Pegawai

Berdasarkan tabel uji parsial (uji - t) di atas, diketahui nilai $t$ hitung dari masing-masing variabel independen secara parsial berpengaruh terhadap variabel dependen yaitu : 
1) Variabel pelatihan memiliki nilai $p$-value (pada kolom Sig.) 0,03> 0,05 artinya signifikan, sedangkan $\mathrm{t}$ hitung 2.705lebih besar dari dari $t$ tabel 1.995 artinya signifikan. Hal ini berarti bahwa pelatihan berpengaruh positif dan signifikan terhadap kinerja pegawai.

2) Variabel kompetensi memiliki nilai $p$ value (pada. kolom Sig.) 0,00> 0,05 artinya signifikan, atau $\mathrm{t}_{\text {hitung }} 6.358$ lebih besar dari $\mathrm{t}$ tabel 1.995 sehingga dapat disimpulkan bahwa kompetensi memberikan pengaruh positif dan signifikan terhadap kinerja pegawai.

3) Variabel komitmen memiliki nilai p-value (pada kolom Sig.) 0,01< 0,05 artinya signifikan, sedangkan $\mathrm{t}$ hitung 3.654> dari $\mathrm{t}$

tabel 1.995 artinya signifikan. Hal ini berarti bahwa komitmen berpengaruh positif dan signifikan terhadap kinerja pegawai.

\subsection{Pengujian Hipotesis dengan Uji - F (ANOVA)}

Hasil uji F menunjukkan variabel independen secara bersama-sama berpengaruh terhadap variabel dependen, jika $p$-value (pada kolom sig.) lebih kecil dari level of sign Ticant yang ditentukan (sebesar $5 \%$ ), atau $\mathrm{F}$ hitung (pada kolom F) lebih besar dari $\mathrm{F}_{\text {tabel }}$.

Sesuai dengan data penelitian tentang pengaruh pelatihan, kompetensi dan komitmen terhadap kinerja pegawai yang dilakukan di Perum LPPNPI Cabang Medan, dapat dihitung nilai $F$ tabel sebagai berikut:

Tabel 5.Hasil Uji Simultan (Uji F) ANOVA $^{\mathrm{a}}$

\begin{tabular}{|l|l|r|r|r|r|r|}
\hline \multicolumn{2}{|c|}{ Model } & \multicolumn{1}{c|}{$\begin{array}{c}\text { Sum of } \\
\text { Squares }\end{array}$} & df & Mean Square & F & Sig \\
\hline \multirow{2}{*}{1} & Regression & 603.260 & 3 & 201.087 & 60.694 & $.000^{\mathrm{a}}$ \\
\cline { 2 - 8 } & Residual & 221.979 & 67 & 3.313 & & \\
\cline { 2 - 8 } & Total & 825.239 & 70 & & & \\
\hline
\end{tabular}

Dependent Variable: Kinerja_Pegawai

Predictors : (Constant), Pelatihan, Kompetensi, Komitmen

Berdasarkan uji $\mathrm{F}$ atau uji Anova atau uji simultan di atas diperoleh $\mathrm{F}$ hitung sebesar 60.684 dengan tingkat kepercayaan $5 \%$ atau 0,05 dengan tingkat signifikan 0,000 karena nilai probabilitas $(0,000)$ jauh lebih kecil dari 0,05 maka model regresi dapat dipakai untuk memprediksi bahwa pelatihan (X1), kompetensi (X2) dan komitmen (X3) sebagai variabel independen secara bersama-sama (simultan) berpengaruh terhadap kinerja pegawai (Y). Dengan kata lain pelatihan (X1), kompetensi (X2) dan komitmen (X3)secara simultan mempunyai pengaruh yang positif dan signifikan terhadap kinerja pegawai, karena $\mathrm{F}$ hitung $>\mathrm{F}$ tabel yakni 60.684> 2,80. Hal tersebut berarti jika pelatihan (X1), kompetensi (X2) dan komitmen (X3) secara bersama-sama diterapkan di dalam lingkungan pekerjaan maka akan berdampak pada kenaikan kinerja pegawai (Y), sebaliknya pelatihan (X1), kompetensi (X2) dan komitmen (X3)secara bersama-sama tidak diterapkan maka akan berdampak pada penurunan kinerja pegawai (Y).

\subsection{Analisis Koefisien Determinasi $(\boldsymbol{R})$}

Untuk regresi linear berganda sebaiknya menggunakan $R$ Square yang sudah disesuaikan atau tertulis Adjusted $R$ Square karena disesuaikan dengan jumlah variabel independen yang digunakan dalam penelitian.

Sesuai dengan data penelitian tentang pengaruh pelatihan, kompetensi dan komitmen terhadap kinerja pegawai yang dilakukan di Perum LPPNPI Cabang Medan, diketahui terdapat lebih dari satu variabel penelitian atau terdapat 3 variabel penelitian, maka analisis regresi penelitian ini adalah dengan melihat nilai dari Adjusted $R$ Square . Nilai Adjusted $R$ Square dikatakan baik jika di atas 0,5 karena nilai $R$ Square berkisar antara 0 sampai dengan 1. Hasil analisis koefisien determinasi dalam penelitian ini dapat dilihat pada berikut ini :

Tabel 6. Hasil Analisis Koefisien Determinasi

Model Summary

\begin{tabular}{|c|c|c|c|c|}
\hline Model & $\mathrm{R}$ & $\mathrm{R}-$ Square & $\begin{array}{c}\text { Adjusted R- } \\
\text { Square }\end{array}$ & $\begin{array}{c}\text { Std.Error Of } \\
\text { the Estimate }\end{array}$ \\
\hline 1 & $.855^{\text {a }}$ & .731 & .719 & 1.82020 \\
\hline \multicolumn{2}{|c|}{ Predictors: (Constant), Komitmen, Pelatihan, Kompetensi }
\end{tabular}


Hasil pengolahan pada tabel di atas terlihat nilai koefisien determinasi $(R)$ yang sudah disesuaikan (AdjustedR Square) sebesar 0,719. Artinya $71.9 \%$ variabel dependen (kinerja pegawai) dipengaruhi atau dijelaskan oleh variabel independen yaitu komitmen, pelatihan, kompetensi dan sisanya sebesar $28.1 \%$ (100\% $71.9 \%)$ dipengaruhi atau dijelaskan oleh variabel lain di luar variabel yang digunakan dalam penelitian ini.

\section{Evaluasi}

4.1. Pengaruh Pelatihan, Kompetensi dan Komitmen terhadap Kinerja Pegawai.

Pada pengujian hipotesis berdasarkan hasil perhitungan dapat dikatakan bahwa pelatihan, kompetensi dan komitmen secara simultan berpengaruh positif dan signifikan terhadap kinerja pegawai di Kantor Perum Lembaga Penyelenggara Pelayanan Navigasi Penerbangan Indonesia ( LPPNPI ) cabang Medan.

Berdasarkan uji $\mathrm{F}$ atau uji Anova atau uji simultan di atas diperoleh $\mathrm{F}$ hitung sebesar 60.694 pada $\mathrm{a}=5 \%$ atau 0,05 dengan tingkat signifikan 0,000 karena nilai probabilitas $(0,000)$ jauh lebih kecil dari 0,05 maka model regresi dapat dipakai untuk memprediksi bahwa pelatihan (X1), kompetensi (X2) dan komitmen (X3) sebagai variabel independen secara bersama-sarna (simultan) berpengaruh terhadap kinerja pegawai $(\mathrm{Y})$. Dengan kata lain pelatihan (X1), kompetensi (X2) dan komitmen (X3) secara simultan mempunyai pengaruh yang positif dan signifikan terhadap kinerja pegawai, karena $F_{\text {hitung }}>F_{\text {tabel }}$ yakni 60.694> 2,80.

Pengaruh positif dan signifikan pelatihan, kompetensi dan komitmen diterapkan di Kantor Perum Lembaga Penyelenggara Pelayanan Navigasi Penerbangan Indonesia ( LPPNPI ) cabang Medan, maka akan meningkatkan kinerja pegawai. Artinya bahwa pelatihan, kompetensi dan komitmen memiliki peranan yang penting dalam meningkatkan kinerja pegawai. Hal ini juga menunjukkan bahwa pegawai merasa mampu selalu mengerjakan pekerjaan dengan teliti sehingga tidak terdapat kesalahan, memiliki pemahaman dan keterampilan yang baik dalam melaksanakan pekerjaan. Pekerjaan yang dilakukan selalu mencapai target yang telah ditentukan, selalu menyelesaikan tugas yang telah menjadi tanggung jawab bekerja dalam kurun waktu tertentu dengan baik dan dengan hasil yang memuaskan. Hasil kerja tidak diragukan lagi karena sesuai dengan standar yang telah ada, tidak pernah menunda pekerjaan yang telah menjadi tanggung jawab. Kinerja adalah hasil kerja secara kualitas dan kuantitas yang dicapai oleh seorang karyawan dalam melaksanakan tugasnya sesuai dengan tanggung jawab yang diberikan kepadanya. Kinerja seorang karyawan merupakan hal yang bersifat individual, karena bagi setiap karyawan kinerja adalah sebuah aksi, bukan kejadian. Aksi kinerja itu sendiri terdiri dari banyak komponen dan bukan merupakan hasil yang dapat dilihat pada saat itu juga. Pada dasarnya kinerja merupakan sesuatu hal yang bersifat individual, karena setiap karyawan memiliki tingkat kemampuan yang berbeda dalam mengerjakan tugasnya. Kinerja karyawan tergantung pada kombinasi antara kemampuan, usaha, loyalitas dan imbalan yang diperoleh.

Program pelatihan, peningkatan kompetensi dan menumbuhkan komitmen organisasi yang terstruktur dan berkelanjutan akan menjadikan karyawan memiliki kinerja tinggi dan dapat memberikan kontribusi kepada kemajuan organisasi.

\subsection{Pengaruh Pelatihan dengan Kinerja Pegawai \\ Berdasarkan penelitian bahwa variabel} penelitian $\left(\mathrm{X}_{1}\right)$ memiliki pengaruh signifikan secara parsial terhadap kinerja pegawai (Y). Hal ni dibuktikan dengan nilai signifikansi t (0.03) $<$ nilai $\alpha=0.05$ ).

Menurut Wibowo (2017: 370), bahwa pelatihan (training) dan pengembangan (development) adalah merupakan investasi organisasi yang penting dalam sumber daya manusia. Pelatihan melibatkan segenap sumber daya manusia untuk mendapatkan pengetahuan dan keterampilan pembelajaran sehingga mereka segera akan dapat menggunakannya dalam pekerjaannya.

Hal ini berarti, bahwa dengan diadakannya pelatihan yang sesuai, baik dan tepat dengan kebutuhan pekerjaan pegawai akan semakin meningkatkan kinerja pegawai.

\subsection{Pengaruh Kompetensi Terhadap Kineria Pegawai}

Secara parsial hasil penelitian ini menunjukan bahwa kompetensi berpengaruhterhadap kinerja petugas Air Traffic Controller ( ATC ) pada Perum Lembaga Penyelenggara Pelayanan Navigasi 
Penerbangan Indonesia ( LPPNPI ) Cabang Medan. Pengaruh tersebut menunjukkan bahwa kompetensi searah dengan kineria pegawai atau dengan kata lain terpenuhinya kompetensi akan berpengaruh terhadap kinerja pegawai yang baik/tinggi. Pengaruh tersebut menunjukkan bahwa kompetensi mempunyai peranan yang penting dalam meningkatkan kinerja petugasAir Traffic Controller ( ATC ) pada Perum Lembaga Penyelenggara Pelayanan Navigasi Penerbangan Indonesia ( LPPNPI ) Cabang Medan.

Berdasarkan hasil penelitian dengan memperhatikan nilai $t_{\text {hitung }}$ pada tabel uji parsial variabel diketahui bahwa kompetensi memiliki nilai $p$-value (pada kolom Sig.) 0,00 > 0,05 artinya signifikan, atau $\mathrm{t}_{\text {hitung }}=6.358$ lebih besar dari $\mathrm{t}$ table $=1.995$, sehingga dapat disimpulkan bahwa kompetensi memberikan pengaruh positif terhadap kinerja pegawai.

Menurut Sutrisno (2019: 203) menjelaskan bahwa pengertian kompetensi dalam organisasi publik maupun privat sangat diperlukan terutama untuk menjawab tuntutan organisasi, di mana adanya perubahan yang sangat cepat, perkembangan masalah yang sangat kompleks dan dinamis serta ketidakpastian masa depan dalam tatanan kehidupan masyarakat. Kompetensi adalah suatu kemampuan yang dilandasi oleh ketrampilan dan pengetahuan yang didukung oleh sikap kerja serta penerapannya dalam melaksanakan tugas dan pekerjaan di tempat kerja mengacu pada persyaratan kerja yang ditetapkan

Dalam penelitian ini telah terbukti bahwa mempunyai kompetensi dalam pekerjaan seperti halnya mengetahui bagaimana melaksanakan pekerjaan yang efektif dan efisien, memahami tugas dan tanggung jawab yang diberikan perusahaan kepada pegawai, mengetahui dan memahami nilai-nilai yang dimiliki perusahaan dengan baik, mempunyai kemampuan untuk menyelesaikan masalah sesuai dengan tugas dan tanggungjawab, percaya sikap baik kepada rekan kerja akan mendukung dalam menyelesaikan pekerjaan yang membutuhkan kerjasama tim, mempunyai minat yang tinggi terhadap pekerjaan yang sayalakukan saat ini dan pengembangan karir kedepannya, selalu sopan dalam berperilaku.

\subsection{Pengaruh Komitmen Terhadap Kinerja Pegawai}

Secara parsial hasil penelitian ini menunjukan bahwa komitmen berpengaruh positif terhadap kinerja pegawai. Dengan kata lain komitmen yang baik dan terprosedur oleh petugas Air Traffic Controller ( ATC ) pada Perum Lembaga Penyelenggara Pelayanan Navigasi Penerbangan Indonesia ( LPPNPI ) Cabang Medan. Hal ini menunjukkan bahwa komitmen dalam bekerja sangat diperlukan untuk diterapkan..

Hal ini dibuktikan dalam hasil penelitian bahwa variabel komitmen memiliki nilai $p$ value (pada kolom Sig.) 0,001<0,05 artinya signifikan, sedangkan $t_{\text {hitung }}=3.654>$ dari $t_{\text {table }}$ $=1.995$ artinya signifikan dan berpengaruh positif terhadap kinerja pegawai.

Menurut Jex and Thomas ( Kaswan 2015:125), komitmen organisasi adalah "The extent to which employees are dedicated to their employing organizations and are willing to work on their behalf, and the likelihood that they will maintain membership. (Definisi ini menyatakan bahwa komitmen organisasi dapat dianggap sebagai tingkat dedikasi pegawai terhadap organisasi tempat dia bekerja dan kemauan bekerja atas nama/untuk kepentingan organisasi, dan kemungkinannya mempertahankan keanggotaannya).

Hal ini berarti bahwa komitmen berpengaruh terhadap kinerja pegawai. Komitmen pada dasarnya adalah merupakan kesedian seseorang untuk mengingatkan diri dan menunjukan loyalitas pada organisasi karena merasakan dirinya terlibat dalam kegiatan organisasi.

\section{Kesimpulan}

Penelitian ini bertujuan untuk melihat pengaruh pelatihan, kompetensi dan komitmen terhadap kinerja pegawai baik secara simultan maupun parsial. Hasil penelitian ini memberikan kesimpulan sebagai berikut :

1) Variabel pelatihan berpengaruh positif dan signifikan terhadap kinerja pegawai ATC di Perum LPPNPI Cabang Medan.

2) Variabel kompetensi berpengaruh positif dan signifikan terhadap kinerja pegawai pegawai ATC di Perum LPPNPI Cabang Medan.

3) Variabel komitmen berpengaruh positif dan signifikan terhadap kinerja pegawai pegawai ATC di Perum LPPNPI Cabang Medan.

4) Variabel pelatihan, kompetensi, dan komitmen berpengaruh positif dan signifikan terhadap kinerja pegawai ATC di Perum LPPNPI Cabang Medan 


\section{DAFTAR PUSTAKA}

Akhyadi, Kaswan 2015. Pengembangan Sumber Daya Manusia . Bandung, Indonesia

Alfabeta

Bintoro dan Daryanto. 2017. Manajemen Penilaian Kinerja Karyawan. Cetakan 1. Yogyakarta : Gava Media. Fathoni, Abdurrahmat. 2009. Organisasi Dan Manajemen Sumber Daya Manusia. Cetakan 1. Jakarta : Rineka Cipta.

Darmawan, D. 2013. Prinsip-prinsip Perilaku Organisasi. Surabaya: Pena Semesta.

Dessler, Gary. 2015. Manajemen sumber Daya Manusia. Edisi 14. Salemba Empat. Jakarta

Fahmi, Irham. 2017. Analisis Laporan Keuangan. Bandung: Alfabeta

Ghozali, Imam. 2016. Aplikasi Analisis Multivariate Dengan Program IMB SPSS 23. Cetakan 8. Semarang : Universitas Diponogoro.

Hasibuan, Malayu S.P. 2017. Manajemen Sumber Daya Manusia. Edisi Revisi, Cetakan 18. Jakarta : Bumi Aksara.

Herman, sofyandi. 2013. Manajemen Sumber Daya Manusia. Cetakan Kedua, Yogyakarta. Graha Ilmu.

Hutapea, Parulian dan Nurianna Thoha. 2011. Kompetensi Komunikasi Plus: Teori, Desain, Kasus dan Penerapan untuk HR dan Organisasi yang Dinamis. , Jakarta. Penerbit: Gramedia Pustaka Utama

Juniarari. (2011). Komitmen Organisasi. Jakarta.

L. Mathis, Robert \& H. Jackson, John. 2011. Human Resource Management (edisi 10). Jakarta : Salemba Empat.

Lijan Poltak Sinambela, 2016, Manajemen Sumber Daya Manusia, Jakarta: PT

Bumi Aksara,

Pabundu Tika, Moh.. 2012. Budaya Organisasi dan Peningkatan Kinerja Perusahaan. Jakarta:Bumi Aksara.

Priansa, Donni Juni. 2014. Perencanaan dan Pengembangan Sumber Daya Manusia. Bandung: Alfabeta

Desi Kristanti, Ria Lestari Pangastuti. 2019 Kiat Kiat Merangsang Kinerja Karyawan Bagian Produksi.Surabaya.Media sahabat cendikia.

Sunyoto, Danang. 2013. Manajemen Sumber Daya Manusia. Jakarta : Center for Academic Publishing Service
Sutrisno, Edy. 2019. Manajemen Sumber Daya Manusia. Edisi Pertama Cetakan ke 10. Jakarta : Prenamedia Group.

Mangkunegara, A.A. Anwar Prabu. 2017. Manajemen Sumber Daya Manusia Perusahaan. Cetakan 14. Bandung : PT Remaja Rosdakarya.

Marwansyah. 2016. Manajemen Sumber Daya Manusia. Edisi kedua. Bandung : CV Alfabeta.

Moeheriono, 2014, Pengukuran Kinerja Berbasis Kompetensi Edisi Revisi, Jakarta: PT RajaGrafindo Persada

Sedarmayanti, 2016, Manajemen Sumber Daya Manusia, Reformasi Birokrasi dan. Manajemen Pegawai Negeri Sipil. Cetakan kelima belas Bandung, Edisi Revisi.PT Refika. Aditama

Sugiyono. 2019. Metode Penelitian Kuantitatif dan Kualitatif. Edisi Kedua Cetakan 1. Bandung : CV Alfabeta.

Veithzal Rivai. 2014. Manajemen Sumber Daya Manusia untuk Perusahaan, Edisi ke 6, Depok PT. Raja Grafindo Persada

Wibowo. 2017. Manajemen Kinerja. Cetakan 12. Depok : Rajawali Pers.

Widodo. 2015. Manajemen Pengembangan Sumber Daya Manusia. Yogyakarta, Pustaka Pelajar, Yogyakarta 